\title{
EFEKTIVITAS MODEL PEMBELAJARAN KOOPERATIF TIPE TTW DENGAN TSTS TERHADAP HASIL BELAJAR MATERI TEORI KINETIK GAS
}

\author{
Siti Nurjanah, Joko Budi Poernomo \\ Jurusan Pendidikan Fisika, Fakultas Saintek UIN Walisongo
}

\begin{abstract}
Abstrak
Penelitian ini bertujuan untuk menganalisa efektifkah penggunaan model pembelajaran kooperatif tipe TTW (Think Talk Write) dengan TSTS (Two Stay Two Stray) terhadap hasil belajar siswa materi teori kinetik gas. Penelitian ini dilakukan di SMA Futujiyyah Mranggen Demak, merupakan penelitian eksperimen dengan posttest only control group design. Populasi pada penelitian ini seluruh siswa jurusan IPA kelas XI SMA Futuhiyyah Mranggen Demak tahun pelajaran 2014/2015. Pengambilan sampel penelitian ini menggunakan teknik simple random sampling dengan mengambil dua kelas secara acak dari populasi sebagai kelas kontrol dan kelas eksperimen. Pengumpulan data menggunakan metode dokumentasi dan metode tes. Analisis uji gain memberikan hasil peningkatan 0.170 untuk siswa yang diajar menggunakan kooperatif tipe Think Talk Write dengan Two Stay Two Stray dan -0,206 untuk siswa yang diajar menggunakan konvensional. Kesimpulannya adalah penerapan model pembelajaran kooperatif tipe Think Talk Write dengan Two Stay Two Stray efektif meningkatkan hasil belajar siswa materi teori kinetik gas.
\end{abstract}

Kata kunci: meningkatkan hasil belajar, TTW, TSTS, model pembelajaran kooperatif. 


\section{PENDAHULUAN}

Proses pembelajaran merupakan jantung dari keseluruhan proses pendidikan formal, karena melalui sebuah proses pembelajaran terjadi transfer ilmu dari guru ke siswa yang berisi berbagai tujuan pendidikan. Guru memiliki peran sebagai pendidik dalam kegiatan belajar mengajar. Sebagai pendidik yang selalu berkecimpung dalam proses belajar mengajar pastilah menginginkan proses belajar yang efektif dan efisien. Maka dari itu penguasaan materi saja tidaklah cukup, seorang guru harus menguasai berbagai model pengajaran yang tepat dan sesuai dengan materi yang akan diajarkan.

Metode mengajar yang dipakai oleh guru akan berpengaruh terhadap cara belajar peserta didik. Agar hasil proses belajar dan mengajar dapat berhasil dengan baik, perlu adanya metode yang tepat dalam proses belajar mengajar yang dilakukan oleh guru dan peserta didik.

Membicarakan tentang metode belajar tentu harus tahu apa itu pengertian belajar, berikut adalah pengertian belajar dari beberapa ahli. Belajar dimulai karena adanya sesuatu tujuan yang ingin dicapai (Rohmah 2012). Belajar adalah perubahan tingkah laku secara relatif permanen sebagai hasil pengalaman (Santrock 2005). Belajar yang efektif adalah melalui pengalaman. Seseorang berinteraksi langsung dengan objek belajar dengan menggunakan semua alat indranya ketika proses belajar berlangsung (Parsons 2001). Belajar adalah menghadirkan perubahan progresif dalam tingkah laku sebagai individu yang bereaksi terhadap suatu situasi atau situasi sebagai 
usaha adaptasi tingkah lakunya secara efektif terhadap permintaan yang dibuat untuk dia (Lester \& Alice 1958).

Hasil belajar disini dijadikan data untuk mengukur efektivitas suatu model pembelajaran, berikut adalah pengertian hasil belajar dari beberapa ahli. Hasil belajar adalah tingkat pernyataan yang dicapai oleh siswa dalam mengikuti program pembelajaran sesuai dengan tujuan pendidikan yang ditetapkan (Khodijah 2014). Menurut A.J. Romiszowski hasil belajar merupakan keluaran (outputs) dari suatu sistem pemrosesan masukan (inputs) (Abdurrahman 2012).

Pembelajaran fisika di SMA Futuhiyyah Mranggen Demak menggunakan metode ceramah dan penugasan (konvensional), pada prosesnyamasih terdapat masalah-masalah pembelajaran sebagai berikut:

1. Penerapan pembelajaran yang kurang bervariasi sehingga peserta didik bosan dan malas ketika proses pembelajaran fisika berlangsung.

2. Pembelajaran cenderung searah.

3. Peserta didik kurang aktif dalam proses pembelajaran.

4. Cukup banyak peserta didik yang menganggap fisika adalah pelajaran yang sulit, terbukti pada waktu diberi tugas tidak semuanya mengerjakan sendiri tapi cukup banyak yang menyontek pekerjaan temannya.

Berdasarkan masalah- masalah proses pembelajaran fisika di SMA Futuhiyyah Mranggen Demak perlu diadakan penelitian tentang model pembelajaran yang dapat mengatasi masalah-masalah tersebut. 
Model pembelajaran yang dapat mengatasi masalah- masalah di atas yaitu model pembelajaran kooperatif dan berpusat pada siswa.

Pembelajaran Kooperatif (cooperative learning) adalah proses belajar mengajar yang melibatkan penggunaan kelompok-kelompok kecil yang memungkinkan siswa untuk bekerja secara bersama-sama di dalamnya guna memaksimalkan pembelajaran mereka sendiri dan pembelajaran satu sama lain (Johnson, dkk. 2012). Ketika dalam lingkungan pembelajaran kooperatif, siswa harus jadi partisipan aktif dan melalui kelompoknya, dapat membangun komunitas pembelajaran (learning community) yang saling membantu antar satu sama lain (Huda 2012).Model pembelajaran kooperatif dapat menjadikan siswa aktif, proses pembelajaran tidak cenderung searah, dan dapat meningkatkan motivasi siswa dalam proses belajar fisika.

Model pembelajaran TTW (Think Talk Write) termasuk pembelajaran kooperatif dan berpusat pada siswa. Ditinjau dari langkah-langkah pembelajarannya model Think Talk Writejuga termasuk model pembelajaran yang beraliran konstruktivisme. ThinkTalk Write (TTW) adalah strategi yang memfasilitasi latihan berbahasa secara lisan dan menulis bahasa tersebut dengan lancar. Strategi Think Talk Write mendorong siswa untuk berpikir, berbicara, dan kemudian menuliskan suatu topik tertentu.Strategi Think Talk Writememperkenankan siswa untuk memengaruhi dan memanipulasi ide-ide sebelum menuangkannya dalam bentuk tulisan.Strategi ini juga membantu siswa dalam mengumpulkan dan mengembangkan ide-ide melalui percakapan terstruktur (Huda 2013). 
Model pembelajaran kooperatif dua tinggal dua tamu (Two Stay Two Stray) dikembangkan oleh Spencer Kagan pada tahun 1992. Model ini bisa digunakan dalam semua mata pelajaran dan untuk semua tingkatan usia anak didik. Struktur dua tinggal dua tamu memberi kesempatan kepada kelompok untuk membagikan hasil dan informasi dengan kelompok lain (Suprijono, 2013). Model ini jika dilihat dari langkah-langkah proses pembelajarannya juga dapat menjadikan siswa percaya diri dan semangat belajar lebih akan timbul karena siswa terlibat langsung dalam proses pembelajaran.

Melalui model Two Stay Two Stray ini, siswa akan bekerja secara berkelompok. Biasanya dalam satu kelompok beranggotakan 4 siswa, 2 orang berperan sebagai tamu dan 2 orang sebagai tuan rumah. Siswa mengerjakan perannya berpasang-pasangan sehingga diharapkan siswa tidak merasa takut dan grogi ketika mengungkapkan hasil diskusi kepada kelompok lain. Hal ini juga menambah kekompakan dan rasa percaya diri siswa. Siswa dikondisikan aktif mempelajari bahan diskusi atau hal yang akan dilaporkan, karena setiap siswa memiliki peran dan tanggung jawab untuk mempelajari bahan tersebut bersama kelompok ketika menjadi tamu maupun tuan rumah. Hal-hal tersebut menjadi menarik untuk di teliti, yaitu dengan memadukan model pembelajaran kooperatif tipe TTW (Think Talk write) dengan model pembelajaran kooperatif tipe TSTS (Two Stay Two Stray)

\section{METODE PENELITIAN}

Penelitian ini dilaksanakan di SMA Futuhiyyah Mranggen Demak tahun ajaran 2014/2015 dengan populasi seluruh siswa jurusan 
IPA kelas XI tahun pelajaran 2014/ 2015 yaitu XI IPA 1, XI IPA 2, XI IPA 3 dan XI IPA 4. Pemilihan sampel dilakukan penggunaan cluster random sampling dan didapatkan kelas XI IPA 1 sebagai kelas kontrol dan kelas XI IPA 2 sebagai kelas eksperimen. Variabel bebas dalam penelitian ini adalah model pembelajaran kooperatif tipe Think Talk Write dengan Two Stay Two Stray dan variabel terikatnya adalah hasil belajar siswa materi teori kinetik gas kelas XI SMA Futuhiyyah Mranggen Demak tahun pelajaran 2014/ 2015.

Penelitian ini merupakan penelitian eksperimen dengan pos test only control group design. Desain penelitian yang menggunakan desain eksperimen ini mengukur kondisi awal siswa dengan nilai UTS siswa kemudian mengukur perbedaan kondisi kelas setelah diberi perlakuan yang berbeda dengan post test dengan sebelumnya memastikan kedua kelas homogen pada keadaan awal.

Instrumen penelitian diuji menggunakan uji validitas, reliabilitas, daya pembeda dan tingkat kesukaran sebelum digunakan untuk evaluasi. Soal evaluasi yang digunakan adalah berupa soal pilihan ganda.

Sebuah tes dikatakan valid apabila mampu mengukur apa yang hendak diukur. Suatu tes dapat dikatakan mempunyai taraf kepercayaan tinggi jika tes tersebut dapat memberikan hasil yang tetap atau reliabel. Soal yang baik adalah soal yang tidak terlalu mudah atau tidak terlalu sukar. Daya pembeda soal adalah kemampuan suatu soal untuk membedakan antara siswa yang pandai (berkemampuan tinggi) 
dengan siswa yang kurang pandai (berkemampuan rendah) (Arikunto 2007).

Metode pengumpulan data dalam penelitian ini menggunakan metode dokumentasi dan metode tes. Data dianalisis melalui dua tahap, yaitu analisis tahap awal dan analisis tahap akhir. Analisis tahap awal yang dimaksud adalah uji normalitas, homogenitas,kesamaan rata-rata nilai awal siswa (menggunakan nilai UTS) untuk mengetahui kemampuan awal siswa. Analisis tahap akhir terdiri atas uji normalitas, homogenitas, perbedaan rata- rata, gain nilai post testkelas sampel setelah diberi perlakuan.

Uji perbedaan rata-rata dilakukan untuk menguji hipotesis komparatif. Hipotesis komparatif adalah pernyataan yang menunjukkan dugaan nilai dalam satu variabel atau lebih pada sampel yang berbeda (Sugiyono 2010).

Uji normalitas digunakan untuk melihat distribusi nilai siswa dalam satu kelas berdistribusi normal atau tidak. Rumus yang digunakan adalah Chi Kuadrat

$$
\chi^{2}=\sum_{i=1}^{k} \frac{\left(O_{i}-E_{i}\right)^{2}}{E_{i}}
$$

Dengan $\chi^{2}$ menunjukkan Chi Kuadrat, $O_{i}$ menunjukkan frekuensi yang diperoleh dari data penelitian, $E_{\bar{i}}$ menunjukkan frekuensi yang diharapkan, dan $\mathrm{k}$ menunjukkan banyaknya kelas interval. Jika $\chi^{2}{ }_{\text {hitung }}<\chi_{\text {tabel }}^{2}$ dengan derajat kebebasan $\mathrm{dk}=4$ taraf signifikan 5\% maka data berdistribusi normal (Sudjana, 2005). 
Uji perbedaan dua rata- rata data hasil post test menggunakan uji t test satu pihak yaitu pihak kanan. Uji ini bertujuan untuk mengetahui apakah penggunaan model pembelajaran kooperatif tipe Think Talk Write dengan Two Stay Two Stray lebih efektif dari pada pembelajaran konvensional. Menurut Sugiyono (2007), rumus uji $t$ yang digunakan adalah:

$$
t=\frac{\bar{x}_{1}-\bar{x}_{2}}{s \sqrt{\frac{1}{n_{1}}+\frac{1}{n_{2}}}}
$$

dengan $\bar{x}_{1}$ : mean sampel kelas eksperimen, $\bar{x}_{2}$ : mean sampel kelas kontrol, $n_{1}$ : jumlah peserta didik pada kelas eksperimen , $n_{2}$ : jumlah peserta didik pada kelas kontrol, $s$ : standar deviasi gabungan data eksperimen dan kontrol. Jika $t_{\text {hitung }}>t_{\text {tabel }}$ dengan taraf signifikan $\alpha=$ $5 \% \mathrm{dk}=\mathrm{n}_{1}+\mathrm{n}_{2}-2$ maka $\mathrm{H}_{\mathrm{o}}$ ditolak dan $\mathrm{H}_{\mathrm{a}}$ diterima. Artinya rata- rata hasil belajar siswa kelas eksperimen lebih baik dari kelas kontrol.

Uji peningkatan hasil belajar (gain) bertujuan untuk mengetahui peningkatan hasil belajar siswa sebelum diberi perlakuan dan setelah diberi perlakuan. Uji ini dihitung menggunakan rumus gain (Hake 1999).

$$
(g)=\frac{\left(\% S_{\text {post }}-\% S_{\text {pre }}\right)}{100-\% S_{\text {pre }}}
$$

$S$ pre $=$ skor rata-rata pre tes dan $S$ post=skor rata-rata post tes . Untuk kategorisasi gain peningkatan hasil belajar adalah sebagai berikut:

$$
\geq 0,70 \quad=\text { tinggi }
$$




$$
\begin{array}{ll}
0,3-0,7 & =\text { sedang } \\
\leq 0,3 & =\text { rendah }
\end{array}
$$

\section{HASIL DAN PEMBAHASAN}

Melalui uji homogenitas tahap awal yang dilakukan pada kelas sampel diperoleh hasil $\chi_{\text {hitung }}^{2}=1,576, \mathrm{dk}=1$, dan $\chi_{\text {tabel }}^{2}=3,84$, $\chi_{\text {hitung }}^{2}<\chi_{\text {tabel }}^{2}$ untuk taraf nyata $\alpha=0,05$ dan $\mathrm{dk}=\mathrm{k}-1$ maka data berdistribusi homogen sehingga bisa digunakan untuk penelitian. Melalui uji $t$ test pihak kanan didapati perhitungan uji perbedaan ratarata hasil akhir penelitian nilai $t_{\text {hitung }}=4,150$ dengan $\mathrm{dk}=38$ dan $t_{(0,95)(38)}=2,02$. Kriteria pengujian yaitu $t_{\text {hitung }}$ dibandingkan dengan $\mathrm{t}_{\text {tabel }}$ dengan taraf signifikan $\alpha=5 \%$ dengan $\mathrm{dk}=\mathrm{n}_{1}+\mathrm{n}_{2^{-}} 2$, jika $t_{\text {hitung }}>t_{\text {tabel }}$, maka $\mathrm{H}_{0}$ ditolak dan $\mathrm{H}_{\mathrm{a}}$ diterima. Hasil perhitungan tersebut menunjukkan bahwa $\mathrm{Ha}$ diterima, artinya nilai rata-rata kelompok eksperimen lebih tinggi dibanding dengan nilai rata-rata kelas kontrol.

Uji peningkatan hasil belajar (gain) kelas eksperimen diperoleh gain 0,17031 dan kelas kontrol diperoleh gain -0,20572. Berdasarkan data tersebut, maka peningkatan hasil belajar materi teori kinetik gas kelas eksperimen yang menggunakan model pembelajaran kooperatif tipe Think Talk Write dengan Two Stay Two Stray lebih baik dibandingkan dengan kelas kontrol yang menggunakan pembelajaran konvensional.

Berdasarkan penelitian ini didapati bahwa model pembelajaran kooperatif tipe Think Talk Write dengan Two Stay Two Stray lebih 
efektif dari pada model pembelajaran konvensional terhadap hasil belajar siswa materi teori kinetik gas kelas XI SMA Futuhiyyah Mranggen Demak. Hal ini dikarenakan model pembelajaran kooperatif tipe Think Talk Write membantu siswa dalam mengkonstruksi pengetahuannya sendiri sehingga pemahaman konsep siswa menjadi lebih baik. Sesuai dengan teori konstrukstivisme yaitu, pengetahuan itu dikonstruksikan (dibangun), bukan dipersepsi secara langsung oleh indra (Suprijono2013). Sementara itu, model pembelajaran kooperatif tipe Two Stay Two Stray disini menjadikan rasa percaya diri siswa bertambah dan meningkatkan motivasi belajar siswa.

Ketika proses belajar mengajar berlangsung dengan menggunakan model pembelajaran kooperatif tipe Think Talk Write dengan Two Stay Two Stray ini, siswa terlihat aktif dan antusias dalam mengikuti proses pembelajaran. Alur yang terjadi pada proses belajar mengajar juga tidak hanya searah guru terhadap siswa, tapi juga siswa terhadap siswa. Keaktifan siswa dalam mengikuti kegiatan belajar mengajar disini menunjukkan bahwa siswa antusias dan semangat ketika kegiatan belajar mengajar berlangsung.

Semangat, keaktifan, rasa percaya diri dan pemahaman siswa yang dikonstruksikan oleh para siswa sendiri ini juga mempengaruhi hasil belajar siswa pada materi teori kinetik gas ketika diterapkannya kegiatan pembelajaran menggunakan model pembelajaran kooperatif tipe Think Talk Write dengan Two Stay Two Stray. Hal ini terlihat dari nilai akhir (pos test) yang menunjukkan nilai rata- rata siswa kelas 
eksperimen yang lebih tinggi dari pada nilai rata- rata siswa dari kelas kontrol.

\section{KESIMPULAN}

Berdasarkan analisis, hasil penelitian dan pembahasan dapat ditarik simpulan bahwa model pembelajaran kooperatif tipe Think Talk Write dengan Two Stay Two Stray efektif dalam meningkatkan hasil belajar siswa pada materi teori kinetik gas kelas XI SMA Futuhiyyah Mranggen Demak. 


\section{DAFTAR PUSTAKA}

Abdurrahman, Mulyono, Anak Berkesulitan Belajar: Teori, Diagnosis, dan Remediasinya, Jakarta: Rineka Cipta, 2012.

Arikunto, Suharsimi, Dasar-Dasar Evaluasi Pendidikan, Jakarta: Bumi Aksara, 2007. , Prosedur Penelitian Suatu Pendekatan Praktek, Jakarta: Rineka Cipta, 2010.

D. Crow, Lester and Crow, Alice, Educational Psychology, New York: American Book Company, 1958.

D. Parsons, Richard, dkk, Educational Psychology, Singapore: Seng Lee Press, 2001.

Departemen Agama RI, Al- Qur'an dan Tafsirnya Jilid V, Jakarta: Lentera Abadi, 2010.

Huda, Miftahul, Model-Model Pengajaran dan Pembelajaran: Isu-isu Metodis dan Paradigmatis, Yogyakarta: Pustaka Pelajar, 2013. , Cooperative Learning Metode, Teknik, Struktur dan Model Pembelajaran, Yogyakarta: Pustaka Pelajar, 2012.

Johnson, David W., dkk., Collaborative Learning, Bandung: Nusa Media, 2012.

Khodijah, Nyayu, Psikologi Pendidikan, Jakarta: Rajawali Pers, 2014.

Rohmah, Noer, Psikologi Pendidikan, Yogyakarta: Teras, 2012.

Sudjana, Metoda Statistika, Bandung: Tarsito, 2005.

Sugiyono, Metode Penelitian Pendidikan: Pendekatan Kuantitatif, Kualitatif, dan R\&D, Bandung: Alfabeta, 2007.

Suprijono, Agus, Cooperative Learning Teori dan Aplikasi Paikem, Yogyakarta: Pustaka Pelajar, 2013.

W. Santrock, John, Psychology Essentials, New York: Mc Graw- Hill, 2005. 